\title{
Van kant gemaak, of met 'n growwer draad geweef?
}

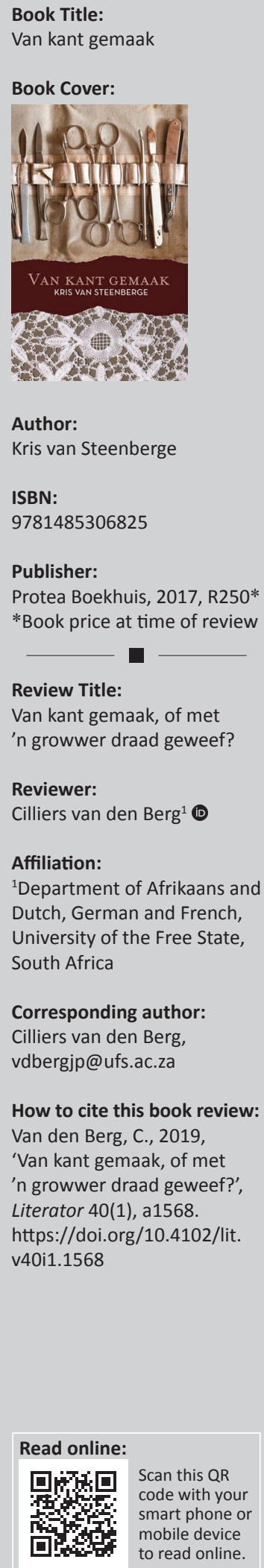

Van kant gemaak is die Afrikaanse weergawe van Kris van Steenberge se debuutroman, Woesten, wat in 2013 in België verskyn het. Die meerduidige titel van Fanie Olivier se vertaling is aan die een kant 'n gelukkige meevaller, synde dat dit na twee handelingselemente verwys wat wél in die vertelling 'n rol speel. Dit verwys enersyds na die fyn versiersels van Belgiese kantwerk en andersyds na 'n konstatering van gewelddadige dood, hetsy binne die konteks van 'n kleindorpse familiegegewe, of verwysend na die Eerste Wêreldoorlog, wat in die roman telkens weer op die agtergrond aanwesig is. Aan die ander kant is die vraag egter in hoeverre die roman as 'n geheel daadwerklik die ragfyn presiesheid van kantversiersels gestand doen en of die narratief nie eerder met ' $n$ growwer draad geweef is nie. Die oorspronklike titel suggereer nie die fyn en subtiele kantstekies van genuanseerde en subtiele karakteriserings, of die tematiese implikasies van versteekte literêre motiewe nie. Inteendeel, Woesten word as "n broeierige verhaal vol dorpsgefluister' beskryf, wat die aard van hierdie teks as dié van 'n dorpsroman bevestig - 'n roman waarin handeling, karakters en temas eerder met breë hale uit die kwas kom.

Die verhaal speel hoofsaaklik in die Belgiese dorpie, Woesten, af en fokus grotendeels op die interaksies (en verskuilde beweegredes) van die Duponselle-gesin: Elisabeth (die meisie wat haar nie van die kleindorpse benepenheid kon bevry nie), Guillaume (die gekwelde dokter wat hom in sy selfopgelegde gevoelens van mislukking en skuld verdrink), Valentyn (die goue seun met 'n geïdealiseerde toekoms, wat nie in staat is om sy verwagtinge te realiseer nie) en Naamloos (die naamlose en stemlose slagoffer van vooroordeel en misbruik, wat uiteindelik op 'n manier tog 'n stem vind). Elke gesinslid is in die groter weefwerk van problematiese en dikwels disfunksionele sosiale verhoudings en omstandighede verwikkel: moeilike moeders, stil of afwesige vaders, verlore geliefdes, priesters wat hulle skuldig maak aan seksuele misbruik, die wreedheid van kinders en die weersin in en selfs vrees vir die onbekende soos vergestalt in mense wat anders is en lyk. Laasgenoemde dui nie bloot op interpersoonlike verhoudings nie, maar ook op die spanning wat tussen die platteland en die stad, of die identiteitspolitiek van 'ons' en 'hulle' bestaan, wat ook die gerugte en werklikhede van die oorlog bepaal.

As 'kantwerk' dan tóg as 'n funksionele metaforiese lens op die teks gerig kan word, is dit veral die verweefde vertelstruktuur wat 'n enigsins komplekser samehang impliseer. Die vyf dele van die roman, 'Vlerke', 'Splinters', 'Verordeninge', 'Bevele' en 'Tweesaam' word respektiewelik vanuit wisselende perspektiewe vertel. Dit word in nabetragting telkens van kardinale belang om belangrike aspekte van die storie te belig, karakters en hulle beweegredes beter te verstaan en uiteindelik ook die narratief op ' $n$ harmonieuse manier af te sluit. Die leser kyk afwisselend deur die oё van die derdepersoonverteller (gekenmerk deur verskillende fokaliserings), maar in die latere dele is daar ook die eerstepersoonperspektiewe van Naamloos en Valentyn - 'n funksionele keuse, deurdat 'Tweesaam' die interafhanklike tweegesprek van beide se perspektiewe word: broers wat mekaar (weer) gevind het en mekaar teen die einde as 'n gesamentlike 'ons'-perspektief aanvul.

Van kant gemaak is uiteindelik 'n samestelling van verskillende generiese elemente: hoofsaaklik 'n dorpsroman, maar ook afgewissel met aspekte behorende tot misdaadfiksie, die familieroman, psigologiese realisme en historiese fiksie. Dit is veral hier waar die fyn kantwerk eerder growwer weefwerk word, aangesien die konvensionele beskrywing en ontwikkeling van beide karakters en gebeure soms effe gekunsteld voorkom. Veral die slot moet hier uitgesonder word, deurdat die bykans té netjiese en gemaklike einde tog effe onoortuigend aandoen. Daar blyk tog ook 'n ongemaklike diskrepansie tussen die slot en die res van die verhaal te wees.

In sy vertalernotas aan die einde van die teks verreken Olivier sommige van die taalkeuses wat hy noodgedwonge moes maak. Desnieteenstaande lei die gebruik van soms ouderwetse Afrikaanse woorde en uitdrukkings daartoe dat die soepelheid van die teks se taalgebruik

Copyright: @ 2019. The Authors. Licensee: AOSIS. This work is licensed under the Creative Commons Attribution License. 
aan bande gelê word en die roman sigself alte dikwels as vertaling aanbied. Dít is op sigself nie noodwendig verkeerd nie, afhangende van watter vertaalteorie deur die ingeligte leser onderskryf word, maar vir 'n gewone leser versteur die soms stywerige formulerings tog die natuurlike fraserings van die Afrikaanse idioom.

Ten spyte van hierdie voorbehoude bied die roman 'n onderhoudende leeservaring, veral vir diegene wie se voorkeur meer na die middelmoot-kant van die literatuurspektrum neig. Dit is weliswaar ook meer as dit: deurdat die narratief verskeie generiese aspekte integreer, maak dit die lees daarvan tog soms ook 'n verrassende ervaring. Van kant gemaak is dalk nie van kant gemaak nie, maar in beginsel vergemaklik 'n growwer draad dikwels die weef van stories met 'n meer populêre appèl. Dat die Afrikaanse vertalingkorpus boonop hierdeur verder uitgebrei word, is ook geensins te versmaai nie. 